удк 330.341

\title{
ПРОБЛЕМИ ФОРМУВАННЯ ЛЮДСЬКОГО КАПІТАЛУ В СИСТЕМІ УПРАВЛІННЯ ПЕРСОНАЛОМ НА ПРОМИСЛОВИХ ПІДПРИЕМСТВАХ МАШИНОБУДІВНОГО КОМПЛЕКСУ УКРАЇНИ
}

\section{PROBLEMS OF FORMING OF HUMAN CAPITAL IN SYSTEM MANAGEMENT BY PERSONNEL AT INDUSTRIAL ENTERPRISES OF UKRAINE MACHINE-BUILDING COMPLEX}

\author{
Могилевська Ольга Юріївна \\ доктор економічних наук, доцент, \\ Київський міжнародний університет \\ ORCID: http://orcid.org/0000-0001-8482-7950 \\ Романова Лідія Василівна \\ доктор економічних наук, професор, \\ Міжрегіональна академія управління персоналом \\ ORCID: http://orcid.org/0000-0003-2292-6616 \\ Слободяник Анна Миколаївна \\ кандидат економічних наук, доцент, \\ Національний університет біоресурсів і природокористування України \\ ORCID: http://orcid.org/0000-0001-6437-0033 \\ Mohylevska Olga \\ Kyiv International University \\ Romanova Lidiya \\ Interregional Academy of Personnel Management \\ Slobodianyk Anna \\ National University of Life and Environmental Sciences of Ukraine
}

\begin{abstract}
Стаття присвячена актуальним питанням визначення пріоритетів стійкого розвитку промислових підприємств, проблемам фрормування людського капіталу в умовах жорсткої конкуренції ринку, інноваційного розвитку виробництва. Розроблено модель розвитку людського капіталу, яка дозволяє виявити чинники, що сприяють або стримують зростання продуктивності праці. Здійснено детальний аналіз системи маркетингових показників розвитку в організаційній культурі промислового підприємства. Визначено, що завдяки поступовому розвитку здібностей співробітників підприємство отримує можливість оптимальним чином використовувати їх потенціал. Доведено, розвиток людського капіталу можливий за умови стійких партнерських відносин зі стейкхолдерами підприємства машинобудівної галузі в стратегії соціально-економічного розвитку регіону та формування ефективної системи управління персоналом на засадах маркетингу.

Ключові слова: конкурентоспроможність промислового підприємства, інноваційне виробництво, стійкий розвиток, організаційна культура, людський капітал, маркетингові показники.
\end{abstract}

Статья посвящена актуальным вопросам определения приоритетов устойчивого развития промышленных предприятий, проблемам фрормирования человеческого капитала в условиях жесткой конкуренции на рынке, инновационного развития производства. Разработана модель развития человеческого капитала, которая позволяет выявить фракторы, роста производительности труда. Осуществлен анализ системы маркетинговых показателей развития в организационной культуре промышленного предприятия. Определено, что благодаря постепенному развитию способностей сотрудников предприятие получает возможность оптимальным 
образом использовать их потенциал. Доказано, развитие человеческого капитала возможено при условии устойчивых партнерских отношений со стейкхолдерами машиностроительной отрасли в стратегии социально-экономического развития региона и формирования эфффективной системы управления персоналом на основе маркетинга.

Ключевые слова: конкурентоспособность промышленного предприятия, инновационное производство, устойчивое развитие, организационная культура, человеческий капитал, маркетинговые показатели.

The article is devoted to topical issues of determining the priorities of sustainable development of industrial enterprises, the problems of human capital formation in conditions of fierce market competition, innovative development of production. The authors emphasize that the paradigm shift in economic development caused by the transformation processes in Ukraine implies the need to build national industrial potential in accordance with the challenges of the new industrial revolution. It is proved that modeling the mechanism of human resources quality management, in turn, will allow to predict, other things being equal, the expected growth of labor productivity, taking into account the current innovation activity in the short term. A model of human capital development has been developed, which allows to identify factors that contribute to or constrain the growth of labor productivity. The necessity of economic-mathematical modeling of human capital development has been proved, which can be used to predict labor productivity depending on the change of human capital quality factors. A detailed analysis of the system of marketing indicators of development in the organizational culture of an industrial enterprise. It is determined that due to the gradual development of the abilities of employees, the company gets the opportunity to optimally use their potential. There is a lack of an effective system of training and retraining of teachers (masters) of vocational education institutions in Ukraine, where the key problems that do not allow the higher education system of Ukraine to develop and improve the quality of education are the lack of an independent system of higher education and the legal mechanism endowment funds, which in turn limits the potential of universities in attracting additional funds to finance research, modernization, implementation of educational innovations. The authors proved that the development of human capital, introduction of innovative technologies, environmental projects in business processes, organizational culture is possible only if a stable partnership with stakeholders of the machine-building industry in the strategy of socio-economic development of the region and the formation of an effective personnel management system. marketing, which is best adapted to market requirements, which contributes to the capitalization of its own brand and increase competitiveness.

Keywords: competitiveness of industrial enterprise, innovative production, sustainable development, organizational culture, human capital, marketing indexes.

Постановка проблеми. В Україні в умовах імпортозалежності виробництва і складного доступу до трансорерту технологічних інновацій, важливість розвитку людського капіталу, як джерела та двигуна створення нових конкурентоздатних виробництв, важко переоцінити. На жаль, в країні не накопичена критична маса інноваційно-активнихпідприємств, забезпечених конкурентоздатними кадрами, що автоматично мінімізує попит на НДДКР. Недостатнє фрінансування державою науки і освіти привело до десріциту на промислових підприємствах кваліфрікованих інженернотехнічних працівників, ослабило партнерські зв'язки 3 науково-дослідними інститутами та закладами вищої освіти. Знищення системи профресійно-технічної підготовки призвело до десріциту високорозрядних робочих на виробництві. I хоча на сьогодні закладений потужний теоретичний фрундамент теорії управління персоналом, ця парадигма вимагає подальшого теоретичного обгрунтування і систематизації наукових досліджень в умовах жорсткої конкуренції ринку, інтелектуалізації виробництва.

Аналіз останніх досліджень і публікацій. Проблемам фрормування людського капі- талу в умовах жорсткої конкуренції ринку, інноваційного розвитку виробництва присвячені праці цілого ряду відомих учених. Серед них слід виділити роботи вітчизняних і зарубіжних учених: Азоєва Г., Балабанової Л., Романової Л., Гавкалової Н., Тарнавскої Н., Барні Дж., Портера М., Прахалада К., Хемела Г. та ін. Досліджені основні аспекти конкурентоспроможності вітчизняного промислового виробництва, виявлено, що фрормування інноваційної організаційної культури в системі управління персоналом сприяє розвитку людського капіталу та дозволяє підприємству повною мірою використати свій конкурентний потенціал.

Виділення невирішених раніше частин загальної проблеми. Проведений аналіз наукової літератури дозволив виявити існуючі розбіжності в поглядах учених з питань оцінки людського капіталу як чинника конкурентоспроможності підприємств, має місце несистемний підхід до формування інноваційної організаційної культури промислового підприємства. Усе це обумовлює необхідність подальшого удосконалення системи управління персоналом, розробки відповідних методів оцінки конкурентоспроможності 
і моделей фрормування людського капіталу в інноваційному середовищі сучасного промислового ринку.

Формулювання цілей статті. Управління підприємством будується на основі усвідомленої бізнес-фрілософрії і групи стратегій. Велике значення науває політика взаємодії 3 внутрішнім клієнтом (персоналом), сукупність цілей, що включає, адаптацію, мотивацію і стимулювання, навчання і розвиток, моніторинг взаємовідносин. Тому доцільним $€$ розвиток існуючих теоретико-методических підходів до інноваційного розвитку організаційної культури промислового підприємства 3 метою підвищення рівня інтелектуалізації виробництва, науково-технічного потенціалу персонала; формування людського капіталу як чинника конкурентоспроможності підприємства.

Виклад основного матеріалу дослідження. Очевидно, що прагнення до зростання продуктивності праці багато в чому визначає стратегію і тактику керівництва компанії, зусилля із нарощування людського капіталу, масштаби впровадження і типи інновацій. За високих темпів скорочення кількості закладів професійно-технічної освіти та кількості учнів Україна зіткнулася з катастрофрічною нестачею квалісрікованих працівників, зокрема, й унаслідок трудової міграції. Фінансування професійно-технічної освіти перебуває на стабільно низькому рівні, незважаючи на потреби закладів в оновленні матеріальнотехнічної бази. В Україні наразі немає дієвої системи підготовки та підвищення кваліфрікації викладачів (майстрів) закладів профресійно-технічної освіти. Ключові проблеми, що не дають системі вищої освіти України можливості розвиватися та підвищувати якість освіти: відсутність незалежної системи оцінювання якості вищої освіти; відсутність правового механізму діяльності ендаумент-фрондів). Це обмежує можливості університетів залучати додаткові кошти для фрінансування наукових досліджень, модернізації, впровадження освітніх інновацій тощо.

Отже, огляд потенціалу промисловості в економіці та обмежень, що стримують розвиток галузі, дає підстави говорити про необхідність удосконалення державної промислової політики, розроблення заходів для адекватного розв'язання існуючих проблем. Зміна парадигми економічного розвитку, викликана трансорормаційними процесами в Україні, передбачає необхідність розбудови національного промислового потенціалу відповідно до викликів нової промислової революції. На нашу думку, рушіями руху до конкурентоспроможного на глобальному ринку виробництва стануть маркетинг стійкості, сучасні технології та інновації, людський капітал, глобальні інвестиції, сприятливе інституційне середовище, державне-приватне партнерство.

Модель розвитку людського капіталу, як економічного об'єкту, підтримується реальними емпіричними даними. Моделювання механізму управління якістю людських ресурсів, у свою чергу, дозволить спрогнозувати за інших рівних умов очікуване зростання продуктивності праці (Y) з урахуванням поточної інноваційної активності на короткострокову перспективу. Досить об'єктивне обгрунтування впливу складових людського капіталу на очікувану величину продуктивності праці можна отримати шляхом побудови регресійної моделі. В якості базових змінних, що описують рівень розвитку людського капіталу, приймемо інтегральні індекси другого порядку: X1 - кількість людських ресурсів в економіці; X2 - вартість людського капіталу; X3 - рівень інноваційної активності середовища фрункціонування людського капіталу; X4 - технічне оснащення середовища функціонування людського капіталу; X5 - освітній рівень розвитку людського капіталу; X6 - якість середовища функціонування людського капіталу; X7 виробничі ризики і фрізичний розвиток людського капіталу.

Вказані чинники складають базову основу моделі розвитку людського капіталу і визначаються шляхом статистичного вивчення процесів, що відбуваються в організації інноваційних процесів. В якості початкових даних для побудови моделі використані параметри розвитку ряду інноваційно-активних промислових підприємств за 2019 рік у галузі машинобудування. У цілях визначення потенціалу кожної складової людського капіталу і її впливу на зростання продуктивності праці, а також виявлення чинників, що обмежують інноваційний розвиток, розглянемо кожну змінну моделі відносно продуктивності праці.

Найбільш сильний зв'язок спостерігається між показниками продуктивності праці (Y) і чинником «Якість середовища фрункціонування людського капіталу» $\left(\mathrm{X}_{6}\right)$. Значення лінійного коефріцієнта кореляції Пірсону складає 0,99. У чинників «Технічне оснащення середовища фрункціонування людського капіталу - Продуктивність праці» проглядається досить сильна лінійна залежність (коесріцієнт кореляції Пірсону складає 0,828). Для 
цієї залежності характерна пряма причинна дія: чим якісніше рівень виробничого середовища, тим вище віддача трудових ресурсів.

Тіснота зв'язку між освітнім рівнем людського капіталу і продуктивністю праці також статистично значима (коесріцієнт кореляції Пірсону - 0,50). Поза сумнівом, обидва аналізовані параметри є украй важливими і мають досить сильний вплив на динаміку розвитку і якість фрункціонування виробництва. Слабка лінійна залежність спостерігається між індексом виробничих ризиків і фрізичного розвитку людського капіталу і результативним показником (коесріцієнт кореляції Пірсону - 0,295).

Для виявлення можливої кореляції між чинниками був проведений кореляційний аналіз. Значення парних коефіцієнтів кореляції представлені в таблиці 1.

Чинник $X_{1}$ має статистично значимий зв'язок з усіма чинниками, за винятком $X_{7}$. Також чинники $\mathrm{X}_{4}$ i $\mathrm{X}_{5}$ пов'язані з чинником X6 i один з одним. Модель була побудована методом покрокового виключення.

Підсумкова модель множинної регресії, що відображає взаємозв'язок результативної ознаки - продуктивності праці з чинниками розвитку людського капіталу в інноваційній економіці, виглядає таким чином:

$$
Y=-0,036-0,023 X_{3}+0,124 X_{5}+0,889 X_{6}
$$

де $Y$ - продуктивність праці; $X_{3}-$ рівень інноваційної активності середовища фрункціонування людського капіталу; $\mathrm{X}_{5}$ - освітній рівень розвитку людського капіталу; $\mathrm{X}_{6}$ - якість середовища фрункціонування людського капіталу.

Чинники $\mathrm{X}_{5}$ i $\mathrm{X}_{6}$ значимі з рівнем значущості, меншим 0,01, a $X_{3}-3$ рівнем 0,1. Коесріцієнт детерміації $\mathrm{R}^{2}$ склав 0,9766, що говорить про хорошу якість моделі: вона пояснює 97,66\% варіації результативного показника. Значення критерію $\mathrm{F}=570$, отже, рівняння значиме.
Рівняння регресії в стандартизованих змінних має вигляд:

$$
t_{y}=-0,043 t_{x_{3}}+0,082 t_{x_{5}}+0,959 t_{x_{6}} .
$$

Це рівняння дозволяє виміряти інтенсивність зв'язку, тобто визначити, в якій мірі зміна незалежних змінних - чинників розвитку людського капіталу пояснює мінливість (варіацію) залежної змінної - продуктивності праці. Так, найбільший вплив на зміну величини продуктивності праці робить якість середовища фрункціонування людського капіталу (бета-коефріцієнт регресії - 0,959). Освітній рівень розвитку людського капіталу (бета-коефріцієнт регресії $0,082)$ робить вже значно менший вплив. Дуже слабо впливає рівень інноваційної активності середовища фрункціонування людського капіталу (бета-коефіцієнт регресії - 0,043).

Оскільки чинниками моделі є індекси, інтерпретація коефріцієнтів моделі скрутна. Замість цього були розраховані приватні коесріцієнти еластичності:

$$
\ni_{y x_{j}}=b_{j} \cdot \frac{x_{j}}{y_{x_{j}} \cdot x_{1} x_{2} . . x_{j-1} x_{j+1} . . x_{k}}
$$

де $y_{\mathrm{xj}} \cdot x_{1} x_{2} \ldots x_{j-1} x_{j+1} \ldots x_{k}-$ приватні рівняння регресії.

Тоді,

$$
\begin{gathered}
\hat{Y} X_{3} \cdot x_{5}, X_{6}=0,623-0,023 X_{3} \\
\hat{Y} X_{5} \cdot x_{3}, x_{6}=0,536-0,024 X_{5} \\
\hat{Y} X_{6} \cdot X_{5}, X_{5}=0,666-0,0889 X_{6} \\
\Im_{Y X_{3}}=-0,023 \cdot \frac{X_{3}}{0,623-0,023 X_{3}}, \\
Э_{Y X_{5}}=0,024 \cdot \frac{X_{5}}{0,536+0,024 X_{5}}, \\
Э_{Y X_{6}}=0,889 \cdot \frac{X_{6}}{0,066+0,889 X_{6}}
\end{gathered}
$$

При зміні чинника $X_{3}$ від 0,13 до 0,76 приватний коефіцієнт еластичності варіюється

Значення парних коефіцієнтів кореляції

Таблиця 1

\begin{tabular}{|c|c|c|c|c|c|c|c|c|}
\hline & $\mathrm{y}$ & $\mathrm{x} 1$ & $\mathrm{x} 2$ & $\mathrm{x} 3$ & $\mathrm{x} 4$ & $\mathrm{x} 5$ & $\mathrm{x} 6$ & $\mathrm{x} 7$ \\
\hline $\mathrm{y}$ & 1 &, 447 &,- 111 &, 211 &, 828 &, 500 &, 984 &, 296 \\
\hline $\mathrm{x} 1$ &, 447 & 1 &, 320 &, 934 &, 583 &, 431 &, 450 &,- 170 \\
\hline $\mathrm{x} 2$ &,- 111 &, 320 & 1 &, 314 &, 036 &, 130 &,- 135 &,- 403 \\
\hline $\mathrm{x} 3$ &, 211 &, 934 &, 314 & 1 &, 324 &, 244 &, 244 &,- 201 \\
\hline $\mathrm{x} 4$ &, 828 &, 583 &, 036 &, 324 & 1 &, 527 &, 848 &, 038 \\
\hline $\mathrm{x} 5$ &, 500 &, 431 &, 130 &, 244 &, 527 & 1 &, 450 &, 071 \\
\hline $\mathrm{x} 6$ &, 984 &, 450 &,- 135 &, 244 &, 848 &, 450 & 1 &, 287 \\
\hline $\mathrm{x} 7$ &, 296 &,- 170 &,- 403 &,- 201 &, 038 &, 071 &, 287 & 1 \\
\hline
\end{tabular}

* Кореляція значима на рівні 0.05 (2-сторін).

** Кореляція значима на рівні 0.01 (2-сторін). 
від -0,029 до -0,005 з середньою еластичністю по $X_{3} \bar{Э}_{\text {X }_{3}}=-0,015$. Таким чином, при збільшенні індексу рівня інноваційної активності на 1\%, продуктивність праці знижується в середньому на 0,015\%. В математичному вираженні незначна зворотна залежність показників може бути обумовлена наступним чинником. Інноваційна активність підприємств, визначувана наявністю витрат на розробку і впровадження інновацій, має деякий часовий лаг між здійсненням інвестицій в інновації, виходом підприємства на високотехнологічний рівень i виробництво інноваційної продукції.

За аналізованими даними, чинник $X_{5}$ мінявся в межах від 0,51 до 0,73. Відповідно, приватний коефріцієнт еластичності - від 0,105 до 0,144 з середньою еластичністю по $X_{5} \bar{\ni}_{Y X_{5}}=0,128$.

Таким чином, при збільшенні індексу освітнього рівня розвитку людського капіталу на 1\%, продуктивність праці збільшується в середньому на 0,128\%. Освіта забезпечує ефективне і раціональне фрункціонування людини як продуктивного чинника.

Проте, домінуючий вплив на Ү робить чинник $X_{6}$. Індекс середовища фрункціонування людського капіталу мінявся від 0,54 до 0,90. При цьому еластичність продуктивності праці по $\mathrm{X}_{6}$ змінювалася від 0,879 до 0,924 з середнім значенням $\bar{\ni}_{Y x_{6}}=0,892$. При збільшенні індексу якості середовища срункціонування людського капіталу на 1\%, продуктивність праці в середньому збільшується на 0,892\%. Підвищення якості виробничого середовища, обумовлене технічним оснащенням і технологічним рівнем розвитку виробництва, поліпшенням умов праці, безпосередньо пов'язано із зростанням продуктивності працівників.

Приймемо, що дельта $(\Delta)$ чинників регресійної моделі умовно складе в даному випадку 10\%. У таблиці 2 представлено, які значення результативного показника очікуються при зміні чинників розвитку людського капіталу на 10\%. У таблиці представлені розрахункові значення для продуктивності праці, отримані за приватними рівняннями регресії та приватними еластичностями (3.5-3.9), при зміні поточного значення чинників на $10 \%$.

Сумарний ефект при збільшенні усіх компонент людського капіталу на 10\% може досягати 9,94\%, тобто збільшення продуктивності праці на 61,032 тис. грн. на людину на рік.

Економіко-математична модель розвитку людського капіталу може бути використана для прогнозування продуктивності праці залежно від зміни чинників якості людського капіталу. Очевидно, що побудована модель відображає вплив чинників у цілому по Україні, а не за окремими категоріями виробників, або для кожного підприємства потрібна буде побудова індивідуальних математичних моделей. Індивідуальні математичні моделі визначатимуть особливості суб'єктів і галузеву специсріку, точніше описувати залежність продуктивності праці від чинників розвитку людського капіталу. Матиме місце дифреренційований підхід до управління розвитком людського капіталу у рамках моделі стійкого інноваційного розвитку підприємства.

Модель розвитку людського капіталу дозволить виявити чинники, сприяючі, або обмежуючі зростання продуктивності праці. Цілеспрямовано впливаючи на змінні моделі, можна умовно управляти динамікою продуктивності праці. В даному випадку людський капітал виступає як об'єкт управління і одночасно $€$ засобом досягнення поставлених цілей, тобто елементом механізму управління у системі упрвління персоналом підприємства машинобудування.

На нашу думку, ровиток вітчизняного машинобудування має відбуватися у системі державно-приватного партнерства на корпоративному та державному (регіональному рівні). Найбільш доцільними напрямами і заходами державної політики роз-

Таблиця 2

Прогнозування рівня продуктивності праці (Y) за умови зміни чинників людського капіталу (X) на підприємствах промисловості України на $\Delta=10 \%$ від існуючого (2020 рік)

\begin{tabular}{|c|c|c|c|}
\hline & $\mathrm{X} 3+\Delta$ & $X 5+\Delta X$ & $\mathrm{X} 6+\Delta$ \\
\hline Значення X & 0,836 & 0,757 & 0,676 \\
\hline$Y_{\text {факт }}$, тис. грн. на людину на рік & 614,072 & 614,072 & 614,072 \\
\hline $\begin{array}{l}Y_{\text {pozрах }} / \Delta Y, \text { тис. грн. на людину на рік, } \\
\text { отримане з використанням еластичності }\end{array}$ & $612,095 /-1,977$ & $623,225 /+9,153$ & $669,421 /+55,349$ \\
\hline $\begin{array}{l}Y_{\text {pospax }} / \Delta Y, \text { тис. грн. на людину на рік, } \\
\text { отримане з використанням еластичності }\end{array}$ & $608,426 /-1,767$ & $618,772 /+4,650$ & $664,808 /+50,736$ \\
\hline
\end{tabular}


витку машинобудівних підприємств мають стати: стимулювання внутрішньодержавного попиту на промислову продукцію; посилення інноваційного та науково-технічного потенціалу галузі, інорормаційна підтримка власних НДДКР; створення інжинірингових центрів, розвиток академічного підприємництва для нарощування науково-технічного потенціалу та імплементації наукових досліджень у бізнес-процеси; стимулювання промислових підприємств до забезпечення перекваліфікації та навчання працівників на виробництві 3 метою підвищення продуктивності праці персоналу, створення умов для безперервного навчання, скорочення плинності провідних працівників; впровадження в освітній процес інноваційних програм їх підготовки відповідно до вимог сучасного промислового бізнесу.

При переході до ринку відбувається поступовий відступ від ієрархічного управління, жорсткої системи адміністративної дії до ринкових відносин і відносин власності, що базуються на економічних методах. Ієрархія відходить на другий план, поступаючись місцем культурі й ринку. У світі, що характеризується процесами глобалізації технологій, які постійно і швидко змінюються, стійка перевага організації може полягати в іїі здатності ефективно акумулювати і поширювати знання. У межах промислової корпорації необхідно прагнути кращого розуміння джерел своїх компетенцій. Де і як провести межу між співпрацею і конкуренцією [3]. Усе зростаюче значення споживача і людського ресурсу у розвитку бізнесу дає поштовх до обґрунтованішого і складнішого аналізу повсякденних економічних переконань і поведінки.

Організаційна культура служить основою формування управлінської культури, але кінцевий результат багато в чому залежатиме від еорективності управлінських практик і процедур, застосування інноваційних методів управління персоналом. Організаційну культуру сучасного промислового підприємства, на наш погляд, можна розглядати на підставі таких характеристик: усвідомлення власних цілей і цілей організації; комунікаційна система і мова спілкування; діловий етикет; трудова етика і мотивація; тайм-менеджмент у загальній системі управління; партнерські стосунки, цінності і норми поведінки; бізнес-орілософрія підприємства; процес профресійного розвитку персоналу; викорисання інноваційних технологій; маркетинг стійкого розвитку [4].
Організаційна культура не є статичною, раз і назавжди встановленою формою відносин у компанії. Зміни, що відбуваються у динамічному зовнішньому середовищі, нерідко приводять до пошуку нових методів управління, нових поведінкових стандартів. Причиною змін у концепції організаційної культури, як звичайно, є освоєння нових видів бізнесу, завоювання нових ринків, зміна кількісного і якісного складу персоналу. Сильна організаційна є потужними важелем управління підприємством 3 метою поліпшення його роботи. Завдання керівництва з фрормування напряму розвитку включає розробку цілей, постановку завдань і фрормулювання стратегії. Реалізація стратегії - це фрункція не лише вищого менеджменту, а робота для всієї управлінської команди, де менеджери несуть відповідальність у межах своїх повноважень і причетності до бізнес-цінностей, що формуються організаційною культурою.

Ключовий фрактор успіху - це фактор, найбільш значущий для успіху. Рішення подібних стратегічних питань визначає конкурентні переваги організації. У той же час ці чинники повинні бути пов'язані 3 ключовими компетенціями організації (core competences) [5]. Завдяки поступовому розвитку здібностей співробітників - набуття практичного досвіду та навчання, якість їх роботи поліпшується, підприємство отримує можливість оптимальним чином використовувати їх потенціал.

Непослідовність здійснення державної політики щодо інноваційного розвитку у системі освіти призвела до зменшення рівня науково-технічного потенціалу України, його стратегічного складника - людського капіталу і у свою чергу, зумовила втрати реальних можливостей інноваційного розвитку промислових підприємств у глобальному ринковому просторі. У XXI ст. найпотужнішою рушійною силою стійкого економічного розвитку країн на міжнародних ринках стає виробництво знань та їх практичне використання. В епоху становлення економіки знань особливого значення набуває питання якості людських ресурсів. Становлення системи безперервної освіти, створення умов для інноваційного та соціального розвитку людського капіталу на промислових підприємствах машинобудування,- це можливість фрормування стійкої конкурентної позиції на ринку [1].

3 метою розробки еорективних маркетингових програм для забезпечення стійкого розвитку промислових підприємств пропонуємо визначати стан науково-технічного потенці- 
алу підприємств на основі аналізу розвитку людського капіталу. В якості результативного індикатора розвитку людського капіталу, на нашу думку, слід використовувати показник продуктивності праці, що характеризує кінцевий результат діяльності людини відповідно до загальних методологічних підходів системи організації виробництва. Продуктивність праці не лише комплексно характеризує накопичені властивості людського капіталу, але і виступає найважливішим індикатором при аналізі тенденцій розвитку інноваційної діяльності і $\epsilon$ ефрективним інструментом прогнозування на мезо- і мікрорівні, стає певним важелем дії на ефрективність виробництва і продуктивність праці, конкурентоспроможність підприємства.
Висновки. Створення конкурентоздатного промислового підприємства нерозривно пов'язане 3 розвитком науково-технічного потенціалу тайого ключового складника-людського капіталу. У свою чергу, розвиток людського капіталу, впровадження інноваційних технологій, екологічних проектів у бізнес-процеси, організаційної культури можливо лише за умови створення стійких партнерських відносин зі стейкхолдерами промислового підприємства машинобудівної галузі в стратегії соціально-економічного розвитку регіону та орормування есрективної системи управління персоналом на засадах маркетингу, яка максимально адаптована до вимог ринку, що сприяє капіталізації власного бренду і підвищенню конкурентоспроможності.

\section{СПИСОК ВИКОРИСТАНИХ ДЖЕРЕЛ:}

1. Балабанова, Л.В., Кривенко А.В. Управління конкурентоспроможністю підприємств на основі маркетингу: монограсрія. Донецьк : Дон ГУЕТ, 2004. 147 с.

2. Гавкалова Н.Л. Управління ефективністю менеджменту персоналу: монографрія. Харків : ХНЕУ, 2011. 295 C.

3. Могилевська О.Ю. Теоретичні підходи до процесу формування організаційної культури в стратегії інноваційного розвитку промислових комплексів. Інвестиції: практика та досвід. 2014. № 22. С. 72-75.

4. Mohylevskaya O.Yu., Romanova L.V., Slobodyanic A.N., Mohylevskyi Yu.V., Shtanko A.I. Marketing approach to the management by innovative development of the region. Sustainable economic development of regions: collective monograph. Austria, Vienna. 2016. Vol. 10, pp. 55-63.

5. Прахалад К.К., Рамасвани В. Будущее конкуренции. Создание уникальной ценности вместе с потребителями. Москва : ЗАО «Олимп-Бизнес», 2007. 352 с.

\section{REFERENCES:}

1. Balabanova L., Kryvenko A. (2004) Upravlinnia konkurentospromozhnistiu pidpryiemstv na osnovi marketynhu: monohrafiia [A management by competitiveness of enterprises on the basis of marketing: monograph]. Donetsk: Don HUET, 147 p. (in Ukrainian)

2. Havkalova N. (2011) Upravlinnya efektyvnistyu menedzhmentu personal: monohrafiia [Managing by effectiveness of personnel management marketing: monograph]. Kharkiv: KhNEU, 295 p. (in Ukrainian)

3. Mohylevska O. (2014) Teoretychni pidkhody do protsesu formuvannia orhanizatsiinoi kultury $v$ stratehii innovatsiinoho rozvytku promyslovykh kompleksiv. [The theoretical approaches to the process of forming of organizational culture in strategy of innovative development of industrial complexes]. Investytsii: praktyka ta dosvid. no. 22 , pp. 72-75.

4. Mohylevskaya O., Romanova L., Slobodyanic A., Mohylevskyi Yu., Shtanko A. (2016) Marketing approach to the management by innovative development of the region. Sustainable economic development of regions. Austria, Vienna, vol. 10, pp. 55-63.

5. Prakhalad K., Ramasvany V. (2017) Budushchee konkurentsyy. Sozdanye unykalnoi tsennosty vmeste $s$ potrebyteliamy. [Future of competition. Creation of unique value together with consumers]. Moskow: ZAO «OlympByznes». 352 p. (in Russian) 